\title{
PELAYANAN KESEHATAN DAN PEMBERANTASAN PENYAKIT TERNAK SAPI BALI DALAM MENDUKUNG PROGRAM SWASEMBADA DAGING SAPI DI DESA BURUAN BLAHBATUH GIANYAR
}

\author{
A.A. G. O. Dharmayudha ${ }^{1}$, Made Suma Anthara², I M. Sukada ${ }^{3}$, dan I B. Komang Ardan ${ }^{4}$, \\ I W Nico Fajar Gunawan ${ }^{5}$
}

\begin{abstract}
ABSTRAK
Pengabdian kepada masyarakat yang dilakukan di desa Buruan, Kecamatan Blahbatuh, Kabupaten Gianyar ini pada intinya bertujuan untuk menekan angka kerugian ekonomi yang disebabkan oleh masalah kesehatan sapi bali. Metode yang digunakan dalam pengabdian masyarakat ini yaitu dalam bentuk pelayanan kesehatan dari rumah ke rumah berupa pemberian vitamin, obat cacing terhadap ternak yang sehat dan melakukan pengobatan terhadap ternak yang sakit, serta diskusi dengan peternak dalam hal ini manjemen pemeliharaan ternak (khususnya sapi bali), serta masalah lainnya seperti penyakit yang umum pada sapi bali dan masalah reproduksi sapi bali. Hasil yang didapat yaitu 22 ekor sapi (20 betina, 2 jantan). Diharapkan melalui pengabdian ini, pada ternak sapi yang sakit akan terjadi peningkatan kesehatan sapi dan menekan angka kejadian penyakit, serta meningkatkan produksi dan kualitas daging sapi secara optimal sehingga program pemerintah yaitu swasembada daging sapi dapat terus terlaksana.
\end{abstract}

Kata Kunci : obat cacing, sapi bali, vitamin

\begin{abstract}
Devotion to the community conducted in the village of Buruan, District Blahbatuh, Gianyar regency in essence aims to reduce the number of economic losses caused by health problems Bali cattle. The method used in this community service is in the form of health services from house to house in the form of providing vitamins, medication worms to healthy livestock and treatment of sick livestock, and discussion with breeders in this case management of livestock (especially bali cattle) as well as other problems such as common diseases in Bali cattle and reproductive problems of Bali cattle. The result is 22 cows (20 females, 2 males). It is hoped that through this dedication, in the sick cattle will increase the health of cattle and reduce the incidence of disease, and increase the production and quality of beef optimally so that the government program that is beef self-sufficiency can continue to be done.
\end{abstract}

Keywords: medicine worming, Bali cattle, vitamins

\section{PENDAHULUAN}

Sapi bali merupakan salah satu plasma nutfah Indonesia yang memiliki potensi besar untuk dikembangkan sebagai pemasok daging dalam jumlah besar. Kemurnian bangsa sapi bali diperlukan untuk perkembangan peternakan di masa mendatang dalam upaya mendukung program pemerintah yaitu

\footnotetext{
${ }^{1}$ Lab. Radiologi Veteriner, Fakultas Kedokteran Hewan, Universitas Udayana, Jl PB Sudirman, Denpasar, Bali, oka.dharma@unud.ac.id

${ }^{2}$ Lab. Farmakologi Veteriner, Fakultas Kedokteran Hewan, Universitas Udayana, Jl PB Sudirman, Denpasar, Bali

${ }^{3}$ Lab. Kesehatan Masyarakat Veteriner, Fakultas Kedokteran Hewan, Universitas Udayana, Jl PB Sudirman, Denpasar, Bali

4 Lab Patologi Klinik Veteriner, Fakultas Kedokteran Hewan, Universitas Udayana, Jl PB Sudirman, Denpasar, Bali

${ }^{5}$ Lab. Radiologi Veteriner, Fakultas Kedokteran Hewan, Universitas Udayana, Jl PB Sudirman, Denpasar, Bali
} 
swasembada daging (Sulistyowati, 2002). Sistem pemeliharaan sapi bali di Bali oleh para petani yaitu dengan cara di gembala (dengan mengikatkan sapi di batang pohon) dan malam hari baru dikandangkan, dan sebagian lagi ada yang dikandangkan terus-menerus (sapi kereman) (Batan 2002). Beberapa penyakit pada sapi bali secara umum dikelompokkan menjadi 2 yaitu penyakit infeksius dan penyakit non infeksius. Penyakit yang disebabkan oleh agen non ifeksius antara lain Baliziekte dan defisiensi mineral.

Salah satu ancaman pada pemeliharaan sapi bali adalah masalah Cacingan atau helminthiasis pada sapi merupakan penyakit infeksius pada tubuh sapi yang disebabkan oleh cacing gilig (Nematoda), cacing pita (Cestoda) atau cacing daun (Trematoda) yang menyerang baik pada saluran percernaan, pernapasan, hati, maupun pada bagian tubuh lainnya. Pada sapi infeksi cacing sering ditemukan pada saluran pencernaan dan hati. Ketiga kelompok cacing tersebut dapat menyerang sapi secara bersama-sama atau sendiri sendiri. Tidak semua specsies cacing dapat menyrang sapi. Beberapa spesies cacing gilig (Nematoda) yang dapat menyerang ternak sapi di antaranya Toxocara vitulorum, Oesophagostomum radiatum, Agryostomum vryburgi, Bunostomum phlebotomum, Trichostrongylus spp., Nematodirus spp., Cooperia spp., Ostertagia ostertagi, Haemonchus placei dan Mecistocirrus digitatus Kasus toxocariasis yang disebabkan oleh Toxocara vitulorum paling sering ditemukan pada pedet (sapi muda). Pada peternakan rakyat dengan sistem pemeliharaan yang masih bersifat tradisional yakni dengan membiarkan ternaknya mencari pakan sendiri meskipun pada lingkungan yang disinyalir telah terkontaminasi dengan cacing akan lebih memudahkan ternak terinfeksi cacing ketimbang sapi yang dipelihara dengan sentuhan pemeliharaan modern (Soulsby 1982).

Perkembangan peternakan sapi di desa Buruan, salah satu desa di kecamatan Blahbatuh, Gianyar masih banyak mengalami hambatan baik itu masalah kesehatan maupun pengetahuan tentang beternak sapi yang baik, sehingga produksinya masih tergolong rendah. Masalah kesehatan dan penyakit yang sering terjadi adalah kematian pedet, diare, cacingan, serta masalah reproduksi yang menimbulkan kerugian ekonomi yang cukup besar.

Dari uraian diatas melalui Lembaga Penelitian dan Pengabdian Kepada Masyarakat Universitas Udayana kami berkeinginan mengamalkan ilmu dan pengetahuan yang kami miliki untuk diabdikan kepada masyarakat sebagai wujud Tri Dharma Perguruan Tinggi.

\section{METODE PEMECAHAN MASALAH}

Pemecahan masalah yang dapat dilakukan dalam kegiatan pengabdian ini nantinya untuk menghindari kerugian akibat masalah kesehatan yaitu dapat dilakukan dengan penerapan manajemen pemeliharaan ternak sapi secara benar dan peningkatan kesehatan sapi. Salah satunya adalah melalui program kesehatan berupa pemberian obat cacing dan vitamin dan pengobatan penyakit ternak sapi lainnya, serta menajemen kebersihan kandang.

\section{HASIL DAN PEMBAHASAN}

\section{Hasil}

Tabel 1. Data Pengabdian Kelompok Tani Ternak Gembala Sejahtera Banjar Buruan, Desa Buruan, Kecamatan Blahbatuh, Kabupaten Gianyar

\begin{tabular}{|l|l|l|l|}
\hline No & \multicolumn{1}{|c|}{ Nama Pemilik } & \multicolumn{1}{c|}{ Jumlah Sapi } & \multicolumn{1}{c|}{ Keterangan } \\
\hline 1. & I Wayan Supiarta & $\begin{array}{l}3 \text { ekor (2 jantan, 1 betina) } \\
\text { I ekor (betina) }\end{array}$ & $\begin{array}{l}\text { vit, obat cacing } \\
\text { vit, obat cacing, gusanex } \\
\text { vit, obat cacing, gusanex } \\
\text { vit, obat cacing } \\
\text { vit, obat cacing }\end{array}$ \\
3. & I Nyoman Nurit & 3 ekor (betina) & vit, obat cacing, butox \\
4. & I Wayan Gunawan & 1 (betina) & \\
\hline
\end{tabular}




\begin{tabular}{|l|l|l|l|}
\hline 5. & I Made Hondos & 1 (betina) & vit, obat cacing, butox, \\
6. & Made Dipta & 4 (betina) & gusanex \\
7. & I Wayan Madra & vit, obat cacing, butox \\
& & vit, obat cacing, butox \\
8. & I Made Londos & 1 (betina) & vit, obat cacing, butox \\
9. & I Wayan Yatna & 1 (betina) & vit, obat cacing, butox \\
10. & I Wayan Nowa & 1 (betina) & \\
11. & Ketut Sukra & 1 (betina) & \\
12. & I Wayan Suwena & 22 ekor (20 betina, 2 jantan) & \\
\hline & Total & & \\
\hline
\end{tabular}

\section{Pembahasan}

Kegiatan pengabdian masyarakat di desa Buruan dilaksanakan pada tanggal 20 Oktober 2017. Adapun pelaksanaannya adalah Program pemberian obat cacing diberikan untuk mencegah terjadinya cacingan yang dapat menimbulkan kerugian ekonomi bagi peternak sapi dan untuk mencegah kematian sapi. Sebagian besar peternak sangat antusias dengan adanya pelaksanaan kegiatan pengabdian ini, hal ini terlihat dari respon peternak dalam mengikuti kegiatan ini yang sangat inin mendapatkan pelayanan kesehatan ternaknya untuk meningkatkan produktivitas ternak mereka. Dari semua ternak sapi yang telah didata, semua mendapat pelayanan berupa spraying/ penyemprotan dengan insektisida. Insektisida yang dipakai adalah Buttox ${ }^{\circledR}$ dengan kandungan zat aktif deltametrin. Konsentrasi yang digunakan adalah 1permil, diperoleh dengan mengencerkan 1ml Buttox ${ }^{\circledR}$ dalam 1 liter air. Selain daerah kepala, spraying dilakukan merata di seluruh tubuh. Fungsinya untuk membunuh lalat yang mengerumuni tubuh sapi serta mencegah lalat hinggap kembali. Seperti diketahui, lalat yang mengerumuni tubuh sapi dapat berakibat buruk. Selain sapi merasa terganggu aktivitasnya, salah satu penyakit yang diakibatkan oleh jenis ektoparasit ini adalah miasis atau belatungan. Disamping itu faktor yang mendorong dalam kegiatan pengabdian ini adalah sebagian besar masyarakat peternak di desa Pering dalam meningkatkan produktivitas ternaknya yang mana sekaligus akan dapat meningkatkan pendapatan mereka dengan menurunnya angka kematian ternak setelah dilakukannya program pelayanan kesehatan yaitu berupa pemberian vitamin, pemberian obat cacing dan penanganan kasus lainnya. Keinginan inilah yang memperlancar pelaksanaan kegiatan pengabdian di desa Pering.

Kendala yang dihadapi dalam pelaksanaan pengabdian ini adalah sebagian besar sapi dari peternak yang sangat kurus dan kekurangan gizi. Hasil pengamatan lapangan dan diskusi dengan peternak menunjukkan sapi terus dikandangkan sedangkan pakan yang diberikan terbatas, disamping kualitas pakan juga rendah. Hal ini setelah didiskusikan/ditanyakan pada peternak ternyata mereka tidak memahami kebutuhan/jumlah pakan yang seharusnya diberikan sesuai kebutuhan sapi. Pada saat diskusi sudah dijelaskan kepada petani untuk memberikan pakan yang lebih banyak dan kualitas pakan ditingkatkan (misal pemberian rumput raja, rumput gajah) tidak jerami atau alang-alang saja. Penambahan dedak/konsentrat pada pakan, serta memberikan/menyediakan air secara ad libitum. Tapi sejauh ini kegiatan pengabdian yang kami lakukan berjalan lancar dan sesuai rencana.

\section{KESIMPULAN DAN SARAN}

\section{Kesimpulan}

Berdasarkan uraian diatas, maka kami dapat tarik suatu kesimpulan sebagai berikut : Dari data yang diperoleh di desa Buruan (di Kelompok Tani Ternak Gembala Sejahtera) dimana jumlah sapi yaitu 22 
ekor (20 betina, dan 2 jantan), dengan kondisi masih banyak terlihat cacingan dan badan kurus dan Kegiatan pengabdian pada masyarakat ini melakukan pemberian vitamin, dan pemberian obat cacing untuk menjaga kesehatan ternak.

\section{Saran}

Dapat kami sarankan bahwa kegiatan pengabdian pada masyarakat ini harus terus kontinyu dilakukan, karena sangat bernilai positif terhadap masyarakat, serta dana untuk kegiatan ini kiranya ditingkatkan sehingga sasaran dari kegiatan pengabdian ini dapat lebih luas dan manfaatnya dapat dirasakan lebih banyak orang.

\section{UCAPAN TERIMA KASIH}

Penulis mengucapkan terima kasih kepada Ketua Lembaga Penelitian dan Pengabdian Kepada Masyarakat Universitas Udayana melalui dana DIPA PNPB sesuai dengan surat Perjanjian Penugasan Pelaksanaan Pengabdian Kepada Masyarakat Nomor : 678-32/UN14.4.A/PM/2017, Dinas Peternakan dan Kesehatan Hewan Kabupaten Gianyar, Petugas UPT Kecamatan Blahbatuh, Aparat Desa dan teman-teman sejawat yang terlibat dalam pengabdian sehingga kegiatan ini berjalan dengan lancar.

\section{DAFTAR PUSTAKA}

Batan, W. 2002 Sapi Bali dan Penyakitnya. Denpasar. UPT Penerbit Universitas Udayana. Bali

Dinas Peternakan Provinsi Bali . 2007. Laporan Tahunan Dinas Peternakan Provinsi Bali. Dinas Peternakan Provinsi Bali

Soulsby, E.J.L. 1982. Helmint, Anthropods and Protozoa of Domesticated Animals . 7th.Ed.Bailliere Tindal London.

Sulistyowati. A. 2002. Upaya Mendongkrak Kembali Populasi Sapi Bali. http://www.kompas.com/kompascetak/0606/16/ekor/2656300.htm.[5 Februari 2016]. 